\title{
Re-verifying the elimination of measles, rubella and congenital rubella syndrome in Canada, 2016-2020
}

\author{
Myriam Saboui ${ }^{1 *}$, Joanne Hiebert ${ }^{2}$, Susan G Squires ${ }^{1}$, Mireille Guay ${ }^{3}$, Patricia Barcellos ${ }^{4}$, \\ Alan Thom ${ }^{4}$, Y Anita $\mathrm{Li}^{1}$
}

Suggested citation: Saboui M, Hiebert J, Squires SG, Guay M, Barcellos P, Thom A, Li YA. Re-verifying the elimination of measles, rubella and congenital rubella syndrome in Canada, 2016-2020. Can Commun Dis 2021;47(11):476-8. https://doi.org/10.14745/ccdr.v47i11a06

Keywords: measles, rubella, congenital rubella syndrome, elimination, surveillance, public health

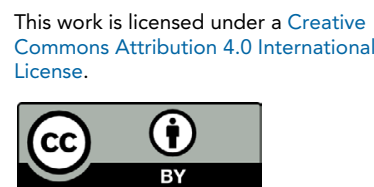

\section{Introduction}

Elimination, in the context of measles, rubella and congenital rubella syndrome (CRS), refers to the absence of endemic measles/rubella virus transmission in a region or other defined geographic area for at least 12 months, in the presence of a high-quality surveillance system that meets targets of key performance indicators. In 1994, Canada and other countries of the World Health Organization (WHO) region of the Americas committed to the objectives of measles elimination by 2000 and rubella and CRS by 2010. Canada met these targets: eliminating measles transmission in 1998; rubella transmission in 2005; and endemically-acquired CRS in 2000. The WHO region of Americas was declared free of endemic rubella/CRS in 2015 and endemic measles in 2016.

At the request of the Pan American Health Organization (PAHO), Canada's elimination status of measles, rubella and CRS was verified in 2012 and again in 2017. Prior to submission to $\mathrm{PAHO}$, the verification reports were reviewed, approved and endorsed by Canada's National Certification Committee (NCC). The NCC is a group of experts who are not directly involved with the management of vaccine preventable diseases or immunization program implementation at the national level, but who have the expertise to assist in ensuring that Canada is meeting PAHO'S goals of elimination and eradication. Members are responsible for reviewing Canada's current mechanisms of surveillance and progress towards elimination of targeted vaccine preventable diseases in Canada. Members have expertise in the fields of public health, infectious diseases and/or laboratory sciences.
Affiliations

${ }^{1}$ Surveillance and Epidemiology Division, Centre for Immunization and Respiratory Infectious

Diseases, Public Health Agency of Canada, Ottawa, ON

2 National Microbiology Laboratory, Public Health Agency of Canada, Winnipeg, MB

${ }^{3}$ Vaccine Coverage and Effectiveness Monitoring Division, Public Health Agency of Canada, Ottawa, ON

${ }^{4}$ Immunization Program Division, Centre for Immunization

Readiness, Public Health Agency of Canada, Ottawa, ON

\section{*Correspondence:}

myriam.saboui@phac-aspc.gc.ca

\section{Current situation}

In early January 2021, Canada received notification from PAHO requesting a country report presenting updated data analyses related to the sustainability of measles, rubella and CRS elimination for the 2016-2020 period. A template was provided by $\mathrm{PAHO}$ using a set of indicators and questions related to five main areas: epidemiology of the diseases; quality of surveillance; laboratory surveillance; analysis of cohort population including vaccine coverage; and sustainability.

In the scope of this request, the NCC was called upon to review the report entitled Re-verification of the Elimination of Measles, Rubella and Congenital Rubella Syndrome (CRS) Elimination, 2016-2020 (1). Specifically, the NCC reviewed the evidence and determined whether the collation of the evidence answered the following questions:
1. Had Canada sustained the elimination of measles, rubella and CRS since the Region of the Americas was declared a region free of these diseases in 2016 and 2015, respectively?

2. Is Canada ready to apply for re-verification of the elimination of measles and/or rubella if it has established that there had been endemic transmission of any of these two diseases?

The report was prepared by the Centre for Immunization and Respiratory Infectious Diseases and the National Microbiology Laboratory, with contributions from the COVID-19 Immunization Readiness Centre (COVID-19; coronavirus disease 2019) and the Centre for COVID-19 Vaccine Surveillance within the Public Health Agency of Canada. The report and supporting documents were approved by the Minister of Health of Canada in early May and then endorsed by the NCC. Canada submitted the NCC-endorsed report, along with supporting documents, to PAHO on June 14, 2021 as requested. 


\section{Results}

Between 2016 and 2020, 199 cases of measles, two cases of rubella and one case of CRS were reported in Canada (Table 1). The range in measles cases reported annually was one to 113, with only one case reported in 2020-prior to the start of the COVID-19 pandemic. Slightly more females than males were affected by measles $(n=111 / 199)$. Among cases where vaccination status was available, $53 \%$ were unvaccinated compared with $46 \%$ of cases who were up-to-date on vaccination. Among the reported measles cases, 80 (40\%) were imported. Nineteen measles outbreaks were reported. The median age of measles outbreak cases was 17 years old (range $0-58$ years). The majority of index cases $(n=17)$ reported travel outside of Canada during their incubation period. The other two index cases included one case who did not travel outside Canada but was potentially exposed to an international case at a Canadian port and one case who did not report any travel outside Canada or exposure to a traveller. Measles strains of genotypes B3 and D8 were detected in Canada between 2016 and 2020 with the genotype D8 named strain MVs/Gir Somnath. IND/42.16/ reported throughout 2019.

Table 1: Pan American Health Organization essential criteria for the verification of the elimination of measles

\begin{tabular}{|c|c|c|}
\hline Criterion $^{\mathrm{a}}$ & Indicator & Description \\
\hline $\begin{array}{l}\text { Verify the } \\
\text { interruption } \\
\text { of endemic } \\
\text { measles cases } \\
\text { for a period of } \\
\text { at least three } \\
\text { years from the } \\
\text { last known } \\
\text { endemic case, } \\
\text { in the presence } \\
\text { of high-quality } \\
\text { surveillance }\end{array}$ & $\begin{array}{l}\text { Zero cases } \\
\text { of endemic } \\
\text { transmission }\end{array}$ & $\begin{array}{l}\text { A total of } 199 \text { cases of measles, two } \\
\text { cases of rubella and one case of CRS } \\
\text { were reported between } 2016 \text { and } \\
2020 \text {. The following is a breakdown } \\
\text { of measles cases by source of } \\
\text { transmission: } \\
\text { Outside Canada: } n=80 \\
\text { Within Canada: } n=94 \\
\text { Within Canada, linked to case/chain } \\
\text { of unknown origin: } n=11 \\
\text { Unknown source: } n=14\end{array}$ \\
\hline $\begin{array}{l}\text { Maintain } \\
\text { high-quality } \\
\text { surveillance } \\
\text { sensitive enough } \\
\text { to detect } \\
\text { imported and } \\
\text { import-related } \\
\text { cases }\end{array}$ & $\begin{array}{l}\text { More than } \\
\text { two suspect } \\
\text { cases per } \\
100,000 \\
\text { population } \\
\text { adequately }\end{array}$ & $\begin{array}{l}\text { Canada does not investigate on } \\
\text { suspected cases of measles, rubella } \\
\text { or CRS. The criterion is met for } \\
\text { laboratory-confirmed cases. }\end{array}$ \\
\hline $\begin{array}{l}\text { Verify the } \\
\text { absence of } \\
\text { endemic } \\
\text { measles virus } \\
\text { strains through } \\
\text { viral surveillance }\end{array}$ & $\begin{array}{l}\text { Measles } \\
\text { genotype } \\
\text { assessed } \\
\text { in } 80 \% \text { of } \\
\text { outbreaks }\end{array}$ & $\begin{array}{l}100 \%(n=20 / 20) \text { of measles } \\
\text { outbreaks had a genotype and } \\
\text { lineage identified. } \\
\text { No outbreaks of rubella occurred } \\
\text { although two sporadic cases } \\
\text { occurred with genotype information } \\
\text { for one. }\end{array}$ \\
\hline
\end{tabular}

Table 1: Pan American Health Organization essential criteria for the verification of the elimination of measles (continued)

\begin{tabular}{|c|c|c|}
\hline Criterion $^{a}$ & Indicator & Description \\
\hline $\begin{array}{l}\text { Verify adequate } \\
\text { immunization in } \\
\text { the population }\end{array}$ & $\begin{array}{l}95 \% \text { of } \\
\text { population } \\
\text { cohorts } \\
\text { aged } 1-40 \\
\text { years have } \\
\text { received a } \\
\text { measles- } \\
\text { containing } \\
\text { vaccine }\end{array}$ & $\begin{array}{l}\text { Canada currently measures } \\
\text { (biennially) measles vaccination } \\
\text { coverage rates at two and seven } \\
\text { years of age, and therefore } \\
\text { is unable to assess measles } \\
\text { vaccination coverage for all ages } \\
1-40 \text { years. The } 2019 \text { childhood } \\
\text { National Immunization Coverage } \\
\text { Survey estimated first dose } \\
\text { measles-containing vaccine } \\
\text { coverage in two-year-olds to } \\
\text { be } 90 \% \text {. }\end{array}$ \\
\hline
\end{tabular}

Abbreviation: CRS, congenital rubella syndrome

a Data from Pan American Health Organization (2)

\section{Conclusion}

The epidemiological and virological evidence presented in the report support that Canada has sustained the elimination of measles, rubella and CRS since the WHO region of the Americas was declared a region free of these diseases in 2016 and 2015, respectively. Despite eliminating measles, rubella and CRS, cases and outbreaks were reported in Canada in the last five years. This is expected to continue until circulation of these viruses is eliminated in all World Health Organization regions. Canadians travelling abroad should continue to ensure they are up-to date on their vaccinations for measles and rubella. Health professionals should remain alert to symptoms of measles and rubella, especially as international travel restrictions related to COVID-19 begin to ease. Canada remains committed to measles and rubella elimination; therefore, continued epidemiological surveillance, including laboratory testing on suspected cases of measles and rubella, is essential.

\section{Authors' statement}

MS - Conceptualization, methodology, software, formal analysis, investigation, data curation, writing-original draft, writing-review and editing, visualization

$\mathrm{JH}$ - Methodology, formal analysis, writing-original draft, writing-review and editing

SGS - Conceptualization, writing-review and editing

MG - Writing-review and editing

PB - Writing-review and editing

AT - Writing-review and editing

YAL - Methodology, review and editing 


\section{Competing interests}

None.

\section{Acknowledgements}

The authors acknowledge the Provinces and Territories for providing data to the Canadian Measles and Rubella Surveillance System and the National Certifying Committee members Dr. Ian Gemmill, Dr. Joanne Embree and Dr. Todd Hatchette for their time and expertise in reviewing and endorsing the Re-verification of the Elimination of Measles, Rubella and Congenital Rubella Syndrome in Canada, 2016-2020 report.

\section{Funding}

This work was supported by the Public Health Agency of Canada.

\section{References}

1. National Certification Committee (Canada). Re-verification of the Elimination of Measles, Rubella and Congenital Rubella Syndrome (CRS) Elimination, 2016-2020. (Unpublished)

2. Pan American Health Organization. Measles elimination in the Americas. https://www3.paho.org/hq/index. php?option=com_content\&view=article\&id=12526: measleselimination-in-the-americas\&ltemid $=40721 \&$ lang $=$ en 